\section{mSiz \\ WICHITA STATE \\ UNIVERSITY}

Wichita State University Libraries SOAR: Shocker Open Access Repository

\title{
A Regression Model of Predictor Variables on Critical Reflection in the Classroom: Integration of the Critical Incident Questionnaire and the Framework for Reflective Thinking
}

Donald L. Gilstrap

Wichita State University

J ason Dupree

Southwestern Oklahoma State University

\section{Citation}

Gilstrap, Donald L. and J ason Dupree. 2008. A regression model of predictor variables on critical reflection in the classroom: Integration of the Critical Incident Questionnaire and the Framework for Reflective Thinking. -- The J ournal of Academic Librarianship, v.34 (8): pp.469-481.

A post-print of this paper is posted in the Shocker Open Access Repository: http://soar.wichita.edu/handle/10057/6640 


\title{
A Regression Model of Predictor Variables on \\ Critical Reflection in the Classroom: Integration of the Critical Incident Questionnaire and the Framework for Reflective Thinking
}

\author{
Donald L. Gilstrap and Jason Dupree
}

\begin{abstract}
This research study investigates the influence of independent variables on students' critical reflection scores in a library instruction program. A student sample $(\mathrm{n}=321)$, enrolled in English Composition II courses, participated in a four-session library instruction curriculum. Brookfield's Critical Incident Questionnaire was used as the main instrument to collect critical reflection data, and the Sparks-Langer et al.

Framework for Reflective Thinking was used as a scoring instrument. Multiple regression analysis was conducted on 4 major theoretical constructs (academic achievement, semester, gender, age) and 6 theoretical assumptions (year in school, previous library instruction, transfer student, librarian, day of week, and time of day).

Significance was found for academic achievement $(p<0.01)$, gender $(p<0.001)$, semester $(p<0.001)$, and year in school $(\mathrm{p}<0.05)$ as predictors of critical reflection.
\end{abstract}

\section{Introduction}

The study of critical reflection is somewhat in its nascent stages. Much is written on the subject as an outcome of quantitative and qualitative research designs or pedagogical techniques. However, little research has addressed critical reflection as the main theoretical construct under study. Although the terms are often used synonymously, there are subtle and distinct differences between critical thinking and critical reflection. The use of the term critical thinking as a theoretical construct in teaching and learning circles appeared during the middle of the twentieth century, and it is defined as "the basis of careful evaluation of premises and evidence and comes to conclusions as objectively as possible through the consideration of all pertinent factors and the use of valid procedures from logic." In more recent years, critical thinking has come to focus on "specific processes of problem solving" through "the ability to analyze propositions

and to assess the extent of their validity." ${ }^{2}$ Critical reflection as a theoretical construct expands on the operational definitions of reflection and critical thinking and can be defined as:

Challenging the validity of presuppositions in prior learning... We very commonly check our prior learning to confirm that we have correctly proceeded to solve problems [e.g. critical thinking], but becoming critically aware of our own presuppositions involves challenging our established and habitual patterns of expectation, the meaning perspectives with which we have made sense out of our encounters with the world, others, and ourselves. ${ }^{3}$

Whitmire's ${ }^{4}$ and Kwon's ${ }^{5}$ studies have opened new doors for the exploration of critical thinking in the classroom, but, to date, there is still little quantitative research in the library science literature on critical thinking. At the same time, critical thinking and critical reflection are foundations upon which the assessment of learning outcomes in library instruction curricula is based on professional guidelines for information literacy. ${ }^{6}$ Moreover, very few research studies 
on critical reflection, and even fewer quantitative studies, exist in the broader social and behavioral sciences literature.

This research study began as an assessment of a library instruction curriculum that had been redesigned to integrate the ACRL standards for information literacy. The study incorporated a mixed-methods approach, using a separate qualitative assessment of the curriculum and a quantitative analysis of critical reflection in the classroom. Results of the qualitative portion of this study are also available for review, ${ }^{7}$ but this article focuses primarily on the quantitative study method. The main purposes of this article, therefore, are to confirm and explain variables that contribute to critical reflection in the classroom while expanding the support of theoretical constructs that exist in the social and behavioral sciences literature. Equally, the article reports on the effectiveness of the combined use of the Critical Incident Questionnaire ${ }^{8}$ and a modified version of the Sparks-Langer et al. Framework for Reflective Thinking ${ }^{9}$ to assess library instruction curricula.

\section{Literature Review}

Borrowing from the theoretical foundations for the use of Brookfield's ${ }^{10}$ Critical Incident Questionnaire (CIQ) as an instrument for assessing critical reflection in the library instruction classroom, our initial literature review was conducted to determine what theoretical constructs were in existence and in mainstream use by social and behavioral science researchers. Although many works discuss and describe critical thinking, most of the theoretical constructs pertaining to critical reflection in student learning rely primarily on the works of Brookfield, ${ }^{11}$ Tripp, ${ }^{12}$ and Woods. $^{13}$

In social development case-study research, Woods ${ }^{14}$ found that gender plays a role in the levels of perceived critical reflection among students. In his findings, often times female students are willing to express themselves at higher, more critical levels than male students. At the same time, Woods found that age also influences differences in social development, as the critical reflections of older adults are expected to express deeper complexity than those of their younger counterparts. Equally, issues such as gender, age, and socio-economic status became "transcended to some degree" the longer individuals within a group worked together to reflect critically on each other's experiences. ${ }^{15}$

Tripp $^{16}$ also developed mainstream theoretical constructs relating to critical reflection in his research on critical incidents in learning. Primarily, the findings of his qualitative research suggest that the influence of gender in classroom reflection is a complex web of socially constructed rules. In Tripp's view, sometimes these cultural mores place female students in positions where they are restricted, or co-opted, from expressing their full potential to reflect critically in the classroom. This view is also supported in mainstream gender studies in psychology. ${ }^{17}$ Equally, Tripp has found that the time of year in which critical reflection is studied influences research outcomes. In effect, Tripp notes that critical reflection takes place at higher levels during the spring semester rather than fall semester based on students' further acclimation to the teaching and learning environment. ${ }^{18}$ 
Brookfield ${ }^{19}$ has also written a great deal on the phenomenon of critical reflection during learning processes. In addition to Woods and Tripp, Brookfield has found that gender plays an integral role in classroom issues of power. Equally, Brookfield addresses academic achievement as an influencing factor in levels of students' critical reflection, although in his experience these correlations do not necessarily develop in a linear manner. In his perspective, other factors such as age, race, socioeconomic status, and gender influence the role of academic achievement in overall critical reflection in different ways.

Although not focusing specifically on the theoretical construct of critical reflection, library science researchers have investigated the role of critical thinking in students' library research. Like Brookfield, Tripp, and Woods, Whitmire ${ }^{20}$ found gender, age, year in school, and academic achievement to be significant predictors in developing critical thinking skills. Whitmire correlated undergraduate students' use of the college library with self-reported scores on the College Student Experiences Questionnaire. In a separate research study, Whitmire found that different critical thinking scores based on user demographics resulted in a need for restructuring library services to encourage wider participation among students. ${ }^{21}$ And most recently, Kwon ${ }^{22}$ utilized the California Critical Thinking Disposition Inventory to investigate the relationship between critical thinking and library anxiety among undergraduate students.

Therefore, the theoretical constructs that exist in the mainstream social and behavioral sciences literature pertaining to critical reflection are used as the foundation for our main independent variables in this study. Based on this literature review, academic achievement, gender, age, and semester serve as the strongest variables from theory that help to explain critical reflection in the classroom. Additional independent variables were also identified by the authors through secondary theoretical constructs that resulted from the research literature, as well as from the theoretical assumptions of the librarians participating in this study. We believed that these secondary independent variables might equally influence the critical reflection dependent variable and include: year in school; whether the student had participated in library instruction before; whether the student had transferred to the institution from another college or university; the librarian who taught the instructional sessions; the day of the week in which the students' participated in instructional sessions; and the time of day in which students participated in instructional sessions. ${ }^{23}$

As is evidenced by the literature in the social and behavioral sciences, critical reflection is a complex process that includes many factors. Therefore, the influences of different variables on students' critical reflection can be problematic when studied. Brookfield developed the Critical Incident Questionnaire (CIQ) as one method for assessing critical reflection in the classroom, thereby helping to improve educational approaches to understand the complexity of this phenomenon in more detail. As an open-ended survey instrument, the CIQ asks students to identify and reflect on critical incidents in the classroom. As a result, we incorporated this instrument into our own curriculum assessment process to capture the critical reflections of students participating in this research study.

Efforts to develop quantitative methods that assess critical reflection have also been investigated recently. Sparks-Langer, Simmons, Pasch, Colton, and Starko ${ }^{24}$ have integrated Gagné ${ }^{25}$ and Van Manen' ${ }^{26}$ theoretical constructs of critical reflection and learning in cognitive psychology with the experiential learning theory of $\mathrm{Kolb}^{27}$ and Schön. ${ }^{28}$ Sparks-Langer et al. thereby 
developed interval measurements to assess critical reflection in learning known as the Framework for Reflective Thinking. As a method to analyze student journaling activities, this model holds promise for assessing critical reflection in quantifiable terms and has been validated in the research literature. As an example, Short and Rinehart ${ }^{29}$ have also applied the SparksLanger framework in the classroom setting, supporting previous studies while showing the impact critical reflection has on student learning and the improvement of problem solving. Incorporating the Sparks-Langer scale to validate and measure significant findings of critically reflective thinking, Short and Rinehart charted transformative periods, indicating perspective changes within students' reactions to problems. Sparks-Langer, Starko, Pasch, Burke, Moody, and Gardner have equally expanded on this framework for reflective thinking to develop further approaches for educational practitioners. ${ }^{30}$ As a validated measure of critical reflection, we additionally incorporated the Framework for Reflective Thinking as a data analysis method to score responses we received from students on the Critical Incident Questionnaires.

\section{Curriculum Overview}

\section{RESEARCH DESIGN}

The purpose of this study was to assess critical reflection in the library instruction classroom and determine what variables might influence this phenomenon. Additional reading is suggested for further exploration of the results and assessment of the qualitative research method component of this study. ${ }^{31}$ This library instruction curriculum had been designed to address multiple instruction sessions for a population of English Composition II students $(\mathrm{N}=752)$ during the course of two semesters. Students participated in library instruction during four consecutive classes. Each of the four sessions included a variety of andragogical techniques, including lecture, group work, hands-on activities, and a time for reflection. The first session introduced students to the research process and included a theoretical framework for understanding database architectures. The second session investigated the differences between scholarly journals and popular magazines while introducing students to concepts such as journal and database aggregators. The third session incorporated database search strategies, as well as news and government documents resources. And the fourth session explored more deeply the evaluation of information tools and resources available on both the open and hidden web.

\section{Data Collection and Analysis}

At the beginning of the first instructional session, students were asked to complete informed consent forms (Table 1). It should be noted that, due to the nature of the qualitative responses and the use of student IDs in the mixed-methods study, informed consent was required for the population of English Composition II students $(\mathrm{N}=752)$. Understandably, not all students chose to participate in the study, and, as a result, the quantitative research from the study of an entire population effectively changed to a participation sample $(n=321)$. As a result, the use of demographic information obtained from non- participants would violate institutional review board policies and, therefore, cannot be included in this study. However, descriptive statistical analysis of the main demographics data (Fig. 1) shows that this study's participants reflect the overall population enrolled in English Composition II classes on key research variables, in general, as is evidenced by the university's Office of Institutional Research statistics. ${ }^{32}$ 
Moreover, an omnibus test was performed to compute sample power estimation very conservatively. ${ }^{33}$ The needed sample size for power as small as 0.10 with a 95 percent chance of rejecting the null for the regression model at $\alpha=0.05$ was determined to be $n=243$. Therefore, the sample used for this research was viewed as an appropriate sample size for a study of this scope, and additional quantitative analyses were incorporated to assess the validity and reliability of the study.

After completing informed consent, students were then asked to fill out a short questionnaire, identifying the independent variables used in the course of this study (Table 2). At the end of each of the four instructional sessions, students were also given a copy of the Critical Incident Questionnaire (CIQ) to complete (Table 3). Information collected from the questionnaire was input into a database by a research assistant, and each of the CIQ response sheets was matched to an individual student based on a primary database key. After all data had been collected for the fall and spring semesters, the authors served as blind reviewers and were given the series of CIQ responses for all of the study participants. All identifying information was stripped from the data sets, and only the responses to the CIQ questionnaires and primary database key were contained. Each blind reviewer was then asked to score the students' responses based on the Framework for Reflective Thinking Scale ${ }^{34}$ modified for the library instruction curriculum (Table 4). Scores were then input back into the larger data set, and median scores were computed from the reviewers' scores for each student.

\section{Hypothesis Testing and Inferential Statistical Procedures}

Reliability measures were then conducted on the use of the instrument and the blind review process. Mean scores on the Framework for Reflective Thinking for Reviewer 1 and Reviewer 2 $\left(\mu_{1}=3.352\right.$ and $\mu_{2}=3.533$ ) were computed. Cronbach's Alpha was then calculated for internal consistency reliability of the instrument based on the blind reviewers' scores, and the intraclass correlation coefficient ( $\mathrm{ICC}=0.791$ ) was measured at a strong level obtained from a two-way mixed model ANOVA ( $\mathrm{F}=9.127, \mathrm{df}(1), \mathrm{p}<0.01)$ (Fig. 2). As an additional measure, intraclass reliability between the blind reviewers' scores was also computed using Pearson's R correlation, since the sample size was large $(n>15)$. Results showed high significance $(r=0.660, p<0.01)$, suggesting that intraclass reliability between the blind reviewers scoring schemas was also high. ${ }^{35}$ Therefore, we concluded that internal reliability for the use of the Framework for Reflective Thinking instrument was at a high level.

Based on the theoretical assumptions in the literature, academic achievement, gender, age, and semester are considered to be possible predictors of reflective thinking, ${ }^{36}$ and a linear regression model was chosen as the method of analysis. Since few research studies have investigated these variables in a quantitative framework, the authors felt that these theoretical constructs would be both explanatory and confirmatory for the purposes of this research. As has been stated previously, the study of the influence of independent variables on critical reflection can exhibit much complexity. Factor analysis was ruled out, as these authors felt that much of the influence of multiple independent variables on the critical reflection scores might become overshadowed by specific factors or become suppressor variables, the explanatory power of the variables would decrease, and the differences in cell sizes by group might skew data outputs. ${ }^{37}$ However, multiple regression analysis helps to explain several independent variables of nominal, ordinal, 
and interval level on the dependent variable while accepting variables that are both strong and weak in their relation to theory. ${ }^{38}$ Therefore, multiple regression analysis was identified as a quantitative framework that would take these issues into account when determining if the variables academic achievement, gender, age, and semester were supported as theoretical constructs that serve as predictors of critical reflection in the classroom while including the additional independent variables.

Coding of nominal and ordinal level data was conducted. Dichotomous variables were binary coded. To preserve their relationships with the grand mean, effect coding was used with categorical and ordinal variables. The two largest categories of the ordinal variable age category were chosen, and category 1 (age $=18$ ) was coded as 1 and category 2 (age $=19$ ) was coded as -1 , the category of reference. The two remaining categories with smaller cell sizes were coded as 0 . Therefore, each category was partialled in contrast with the other categories. For the categorical variable librarian code, the two largest cell sizes were chosen. Librarian category 2 was coded as -1 for the reference category, and librarian category 3 was coded as 1 . The two remaining categories were coded as 0 , and each category was subsequently partialled in contrast with the other categories. $^{39}$

After categorical and ordinal variables were effect coded, a series of preliminary tests were conducted to determine if the authors of this article should continue with the multiple regression analysis. Since the theoretical constructs for this study resulted primarily from qualitative research, preliminary correlation analysis was performed on two continuous variables-reflective thinking scores and academic achievement-and the strength of association between these two variables was found to be high $(\mathrm{p}<0.001)$. Based on the theoretical assumptions in the literature, gender, age, and the semester in which students participate in critical reflection assessment activities are also believed to be possible predictors of reflective thinking. Our preliminary hypotheses were, therefore, as follows:

$H_{0}=$ There is no significant difference

between mean scores of reflective thinking

based on gender, semester, and age.

$H_{1}=$ There is a significant difference between

mean scores of reflective thinking based on

gender, semester, and age.

Independent samples T-tests were then conducted on these hypotheses for each dichotomous and categorical variable. Observed differences in means based on gender was highly significant $\left[\mathbf{x}_{\text {Male }}=3.083, \mathbf{x}_{\text {Female }}=3.721, \mathrm{t}(321)=-4.951, \mathrm{p}<0.001\right)$. Levene's Test for Equality of Variances for gender was 0.818, showing that the assumption of homogeneity was strong for this hypothesis. Observed differences in means based on semester was also highly significant $\left[\mathbf{x}_{\text {Fall }}=\right.$ $\left.3.909, \mathbf{x}_{\text {Spring }}=3.246, \mathrm{t}(166.069)=-4.431, \mathrm{p}<0.001\right)$ although Levene's Test for Equality of Variances was 0.003, showing that variances between the two samples were not equal. Confidence interval information for both variables, however, showed that the null hypotheses did not fall within the interval, and the null hypotheses could be rejected. Therefore, considering the significance levels $(\mathrm{pk}<0.001)$ and confidence levels for these variables, gender and semester, as well as academic achievement, proved to be significant predictors on critical reflection scores. 
However, age was not found to be significant in the preliminary T-test for this study, using both categorically and effect coded data in separate tests. We then proceeded to expand our framework for theoretical exploration to the multiple regression model, incorporating the additional independent variables with the main theoretical variables $(\mathrm{k}=10)$.

\section{Research Findings}

Multiple regression was conducted on the dependent variable, reflective thinking scores, and the following independent variables were entered simultaneously in one step into the model: academic achievement, gender, semester, age, year in school, previous library instruction, transfer student, librarian, day of week, and time of day. An ANOVA test of the strength of significance of the regression model was found to be highly significant $[F(10)=8.104, p<0.001]$, protecting against the likelihood of Type I errors, with a moderate effect size above the 60 percentile standing $\left(\mathrm{R}^{2}=0.202\right)$ in relation to the expected effect size $[\mathrm{k}(10-1) / \mathrm{n}(348-1)=0.026]$ (Fig. 3). ${ }^{40} \mathrm{~A}$ histogram of frequencies on mean critical reflection scores showed that the assumption of normality was met for the sample (Fig. 4). Normal P-P and scatter plots of standardized residuals showed that observed and predicted residuals followed the regression line tightly and were normally and randomly distributed, therefore meeting the assumptions of homoscedasticity and linearity (Figs. 5 and 6). ${ }^{41}$

The regression model revealed that the following independent variables drawn from theory ${ }^{42}$ were found to be highly significant: academic achievement $(p<0.01)$, gender $(p<0.001)$, and semester $(p<0.001)$ (See Fig. 7). Age, another variable drawn from theory, was not found to be a significant predictor of critical reflection as was expected from the literature. The following independent variable included in the model based off of theoretical assumptions $(\mathrm{k}=7)$ was also found to be significant: year in school $(\mathrm{p}<0.02)$. The remaining independent variables based on theoretical assumptions were not found to be significant and include: previous library instruction, transfer student, librarian, day of week, and time of day.

As many statisticians in the social and behavioral sciences have noted, multiple regression is a robust test for exploring the influence of independent variables on the dependent variable while also analyzing the degree of interaction between each of the independent variables. However, the more variables that are included in the model, the increased likelihood of interaction effects, ${ }^{43}$ particularly when multiple categorical variables are involved, ${ }^{44}$ as is the case with this and many other multiple regression studies. Collinearity diagnostics were performed, therefore, given that 10 independent variables were included in the regression model (Fig. 8). Variance Inflation Factor scores $\left(\mathrm{VIF}_{k} \leq 1.439\right)$ and Tolerance levels (Tolerance $\left.\mathrm{k}_{\mathrm{k}} \geq 0.695\right)$ showed that the independent variables fell within very acceptable, non-collinear ranges. ${ }^{45}$ However, further diagnostics suggested a possibility of multicollinearity, being that the condition index at the eleventh dimension of the model constant was 21.223. In the case of these ten independent variables, interaction effects might be taking place at some dimensions of the regression model. However, when multicollinearity is found even in a high condition index $(>30)$, this should not indicate an omnibus test for rejection of the multiple regression model; rather possible interaction effects should be discussed using a descriptive framework. ${ }^{46}$ 
Although the condition index score in the collinearity diagnostics was not high, additional analyses were performed. As state previously, the ANOVA test of the strength of the model was highly significant $(\mathrm{p}<0.001)$. Additionally, bivariate correlations between the variables $(\mathrm{r}=>.80)$ would signal significant interactions, ${ }^{47}$ and no correlations were found $\left(\mathrm{r}_{\mathrm{k}}<=0.211\right)$. The sum of individual effects for each of the independent variables $\left(\Sigma \mathrm{R}^{2} \mathrm{i}=0.186\right)$ did not surpass the effect size of the main regression model $\left(\mathrm{R}^{2}=0.202\right) .{ }^{48}$ There was a lack of unstable partial coefficients, a lack of large confidence intervals, and a lack of large standard errors further suggesting that multicollinearity had been over-stated in the condition index. ${ }^{49}$ Since high multicollinearity diagnostics also present the possibility of skewed variance in coefficient scores ${ }^{50}$ ridge regression $[\mathrm{k}=0.1, \mathrm{~F}(10)=7.948, \mathrm{p}<0.0001]$ has been computed for comparison purposes (Fig. 9). Observation of these comparison scores show there are not significant differences between multiple regression analysis and ridge regression analysis coefficients. The authors of this article, therefore, chose to continue to include all of the independent variables originally hypothesized since: power and accuracy of the multiple regression model would suffer in stepwise regression strategies; ${ }^{51}$ the use of the multiple regression model in this study was to explain and confirm the power of the theoretical constructs surrounding critical reflection in the classroom $;{ }^{52}$ dropping variables from the model due to the possibility of multicollinearity can cause much greater problems of specification bias in the model; ${ }^{53}$ and, finally, all analyses previously stated, other than the model's condition index, suggest a low chance of multicollinearity in the model. But perhaps the condition index equally reinforces the complex and interconnected nature of variables that contribute to critical reflection in the teaching and learning environment.

\section{Limitations of the Study}

Although this study incorporated a fairly large sample size, limitations do exist within this research. Only one institution is studied, and the demographics and focus of the institution can have some bearing on the results. At the same time, socioeconomic status was also identified in the main literature review as an influence on critical reflection in the classroom. Due to the nature of this research, and the incorporation of the qualitative research method, this variable proved problematic from an institutional review board perspective and was excluded from this research study. It must also be noted that, since the linear regression model was used for the basis of quantitative analysis, findings should not be inferred to equate causation. Equally, although collinearity analyses are addressed, interaction effects should not be discounted in studies of very complex phenomena such as critical reflection and are addressed in descriptive terms in this research. Moreover, we return to the theoretical constructs surrounding critical reflection in the classroom, and we argue that, by its very nature, this dependent variable encompasses far more independent variables than are included in this study. Future studies investigating more or different variables might help to explain increased effect sizes and differences in coefficient analyses. Additionally, studies using both linear and nonlinear regression ${ }^{54}$ on variables not included in this research would contribute greatly to the further explanation of critical reflection in learning environments.

\section{Discussion of Findings}


The results of this study reveal many things about critical reflection in the classroom. Of greatest significance, the mainstream theoretical constructs, namely academic achievement $(\mathrm{p}<0.01)$, gender $(p<0.001)$, and semester $(p<0.001)$, were supported as predictors of critical reflection during this study. Regarding academic achievement, a review of descriptive statistics (Fig. 1) suggests that students with lower academic achievement scores tended to score lower on the critical reflection score instrument, whereas students with higher academic achievement scores tended to score higher on the critical reflection instrument. The high significance of the findings for this variable confirms academic achievement as a predictor of critical reflection. Furthermore, Brookfield, ${ }^{55}$ has argued that the phenomenon of critical reflection sometimes contradicts this linear relationship between academic achievement levels and reflection. Although mean scores on critical reflection were greatest for the highest quartile on academic achievement (GPA=3.0-3.4, $\mathrm{x}=3.557)$, descriptive statistics from our study do tend to support Brookfield's observation of this phenomenon. Mean scores on critical reflection at the lowest quartile for academic achievement $(\mathrm{GPA}<=1.9, \mathrm{x}=3.100)$ were actually higher than mean scores for the second quartile (GPA=2.0-2.4, $\mathrm{x}=3.016)$, although mean scores rose for each succeeding quartile. Additionally, analysis of zero-order and partial correlations (Fig. 10) shows that academic achievement accounts for $3 \%$ of the variance in overall critical reflection, and, as a predictor, academic achievement accounts for $2.16 \%$ of the variance in critical reflection above the variance accounted for by the nine other predictor variables while taking into account this variable's significance at both lower and higher academic achievement levels. Further research on different populations is suggested to help explain the importance of academic achievement as a theoretical construct in more detail.

The findings for this study also confirm with extremely high significance $(p<0.001)$ that gender is a predictor of critical reflection in the classroom. In general, female students $(x=3.721)$ tended to score higher than their male peers $(x=3.083)$ on the critical reflection instrument (Fig. 1). These findings support Tripp and Woods ${ }^{56}$ arguments that female students are more comfortable with reflecting and expressing their perceptions of the learning environment in a critical manner. These findings might also suggest that the support mechanisms found in the university atmosphere contribute to breaking down gender biases, as suggested previously in the literature, while further encouraging confidence and selfefficacy in critical reflection among female students. Equally, this study adds support to Whitmire's ${ }^{57}$ finding of gender as a predictor in studies of critical thinking in library instruction. Additionally, analysis of zero-order and partial correlations (Fig. 10) shows that gender accounts for $7.3 \%$ of the variance in overall critical reflection, and, as a predictor, it accounts for $7.1 \%$ of the variance in critical reflection above the variance accounted for by the nine other predictor variables. In the case of this research study, the authors observed that male students had a more difficult time "challenging the validity of presuppositions in prior learning," 58 in relation to the critical nature of the Framework for Reflective Thinking. The authors of this article, therefore, encourage other researchers in the social and behavioral sciences to investigate this phenomenon in further detail, as well as to explore the influence of additional independent variables on gender in the assessment of critical reflection in the classroom.

The semester in which students participated in library instruction also confirmed this variable with extremely high significance $(\mathrm{p}<0.001)$ as a predictor of critical reflection in the classroom. Additionally, students who participated during the fall semester scored higher $(x=3.909)$, in 
general, than students who participated during the spring semester ( $x=3.246$ ) (Fig. 1). On first observation, a converse relationship appears to emerge in this study in relation to the predicted theoretical construct, because the literature suggests that students are more acclimated to the academic community during the spring semester and are, therefore, more comfortable and confident in expressing themselves in a critically reflective manner. However, further review of descriptive statistics shows that sophomore students $(x=3.589)$ had higher mean scores than freshman students $(x=3.408)$. This observation suggests that academic acclimation had already taken place, since sophomore students had waited until their second academic year during the fall semester to take the English Composition II course. Moreover, analysis of zero-order and partial correlations (Fig. 10) shows that semester accounts for $7.1 \%$ of the variance in overall critical reflection while, as a predictor, it accounts for $6.7 \%$ of the variance in critical reflection above the variance accounted for by the nine other predictor variables.

Year in school, one of the variables drawn from theoretical assumptions, was also found to be significant $(\mathrm{p}<0.02)$. As a predictor, it accounts for $1.5 \%$ of the variance in critical reflection above the variance accounted for by the nine other predictor variables. Further analysis of descriptive statistics shows that sophomore students $(x=3.589)$ had higher mean scores than freshman students $(x=3.408)$, and senior students $(x=3.350)$ had higher mean scores than junior students $(x=3.214)$. Why these differences exist between categories within lower level and upper level students is beyond the scope of this research study. However, consideration of the theoretical assumptions surrounding acclimation to the academic environment might suggest that students were further acclimated during their sophomore year but still had not begun to take a majority of classes for their majors. As seniors, students were most likely the most acclimated to the academic environment which might suggest why their scores are higher than for those of juniors. However, as seniors, students take a large portion of their major coursework, and general education courses taken during upper level status might become secondary in importance for these students in comparison to freshmen and sophomores. Further research is suggested to investigate this phenomenon in more detail.

The significance of semester and year in school as predictors of critical reflection, in combination with these descriptive statistics, supports the theoretical construct that acclimation into the academic learning environment increases the power of critical reflection in the classroom. These findings suggest that librarians should review the primary student focus of their library instruction curricula. A somewhat discomforting challenge for all of us might be to assess with scrutiny whether library instruction courses are more beneficial in eliciting critical reflection in the classroom further along in a student's academic career as opposed to the cursory instructional sessions we might provide incoming students in freshman orientation/experience classes. Along these same lines, would library instruction have an even greater impact on students' critical reflection after they had begun coursework specifically in their majors? Further research and a continuing dialogue in the professional literature would be needed to investigate this phenomenon in more detail.

Age was not found to be a significant predictor of critical reflection in the library instruction classroom in the multiple regression analysis. Furthermore, descriptive statistics revealed that the highest age quartile mean score ( $\operatorname{age} \geq 30, \mathrm{x}=3.300$ ) was actually the lowest mean score of the quartiles, suggesting a negative relationship between age and critical reflection in the library 
instruction classroom. Although other factors could influence this, such as the difficulties of returning to school, the theoretical construct from the literature suggesting that critical reflection improves with age was not supported in this study. However, experience is discussed with great detail among many authors of critical reflection research. In contrast to age as an indicator of experience, and the subsequently inferred prediction of age on critical reflection, perhaps life experiences, regardless of age, might serve as a stronger theoretical construct in future studies. Further research is encouraged to investigate the nature of the relationship between age and life experiences and how the interaction between these variables influences students' critical reflection in the classroom.

The remaining independent variables were not found to be significant predictors in the multiple regression model. However, it is important to note a few observations by these researchers. Although time of day was not found to be a significant predictor, in relation to the other variables chosen in the study, additional observations of descriptive statistics show that it is still an important variable. Mean scores for students who participated in library instruction during morning sessions $(x=3.514)$ were higher than for students who participated during afternoon sessions $(x=3.162)$. Additionally, this was one of the main variables contributing to the inflation of the condition index in collinearity diagnostics (Fig. 8). Although it can be inferred through educational practice that this is an assumed phenomenon with which we are all familiar, further research is encouraged to investigate how the time of day in which students participate in library instruction affects their critical reflection in the classroom.

Previous library instruction also was not found to be a significant predictor for critical reflection. The authors of this article found this lack of significance to be contradictory to what might be inferred by most of us teaching library instruction. A basic theory of practice assumption might be to argue that successive library instruction courses throughout a student's academic career would help improve his/her ability and desire to reflect critically on the knowledge gained each time in the classroom. However, mean scores for students who had no previous library instruction $(x=3.505)$ were actually higher and standard error of the mean scores $\left(\mathrm{SE}_{\mathrm{x}}=0.0833\right)$ lower than for those students who had received library instruction previously $(x=3.357$, $\left.\mathrm{SE}_{\mathrm{x}}=0.1094\right)$. When taken in relation to the significant predictor year in school, both freshman and sophomores had higher mean scores if they had not taken library instruction previously, whereas juniors and seniors had higher mean scores if they had previously received library instruction. As was stated earlier, in addition to students being more acclimated to the academic environment when studies of critical reflection are performed, this observation helps to reinforce that librarians might question whether more effort should be placed on developing curricula that emphasize library instruction later on in a student's academic career, particularly focusing on the period when a student is taking a large portion of the classes for his/her major [e.g. junior and senior years]. Equally challenging might be to determine if repeated library instruction in the classroom, commencing during a student's first semester, may actually contribute to a negative relationship to broader success in library research self-efficacy throughout his/her academic career. These authors suggest that longitudinal studies should be conducted on different student populations to determine whether there is support for this hypothesis while equally investigating this phenomenon in relation to mainstream theory in the transfer of learning. ${ }^{59}$ 
From the perspective of library instruction curriculum assessment, this research study was viewed as a success by these authors. The use of the Critical Incident Questionnaire in combination with the Framework for Reflective Thinking made possible the facilitation of a qualitative data collection instrument being transformed into quantitative data. Perhaps the use of these two instruments also highlights the complex nature of critical reflection and the need to study this phenomenon from both a qualitative and a quantitative framework. Furthermore, the use of these two instruments in cohort provides educators of information literacy with one method for the effective assessment of professionally proscribed standards for library instruction. ${ }^{60}$ When following the blind review process of scoring the Critical Incident Questionnaire instruments with the Framework for Reflective Thinking instrument, rater schemas were found to be highly correlated with strong internal reliability $(\mathrm{ICC}=0.791, \mathrm{~F}=9.127$, $\operatorname{df}(1), \mathrm{p}<0.01)$.

Anticipation by many educators might suggest that a positively skewed sample on critical reflection would equate to a more successful curriculum outcome. The fact that the grand mean score for students in this study was 3.44 implies that the majority of students did not exhibit critical reflection scores above "explanation with tradition or personal preference given as the rational" (Table 4). However, mean scores for students on critical reflection followed the normal curve, increasing the validity of the study while showing that this assessment technique could serve as a standard for helping to explain the phenomenon of critical reflection in the classroom.

\section{Conclusion}

Overall, the authors have found the integration of the Critical Incident Questionnaire to be successful in identifying critical reflection and areas for improvement in the library instruction curriculum. As an extension of this study, this instruction program has implemented an online feedback form to be completed by students after each class is taught. This feedback mechanism mirrors the CIQ questions to gage continuously the critical reflections of students. Furthermore, as instruction librarians continue to modify and adapt the curriculum, this assessment tool will help librarians evaluate and respond more quickly to both the positive and negative aspects of the teaching and learning experience.

This study has also demonstrated the importance of confirming and explaining the strongest variables drawn from the theoretical literature and assumptions on the critical reflection process through the use of the Framework for Reflective Thinking. Academic achievement $(\mathrm{p}<0.01)$, gender $(p<0.001)$, semester $(p<0.001)$, and year in school $(p<0.02)$ were significant variables in this study. The authors contend these significant variables, the non-significant variables, and additional untested variables should be explored at other institutions to explain the phenomenon of critical reflection in different teaching settings. Equally, librarians should continue further dialogue and assessment of when library instruction is offered to students-and the influence of time and academic matriculation as variables - to elicit deeper understanding of critical reflection. Moreover, it must be reinforced by these authors that many unexplored variables most likely contribute to the complex nature of the critical reflection phenomenon in the classroom. Further research is encouraged to help establish more defined theoretical constructs that impact students' critical reflection and subsequent self-efficacy in information literacy during their academic careers. 
Acknowledgment: The authors wish to thank Janet Grabeal, Assistant to the Director, SWOSU Libraries, for her assistance in compiling data used in this study. 


\section{Figures and Tables}

\section{Table 1-Student Consent Form}

You are invited to participate in a research study conducted by the SWOSU Libraries about your participation in the Library Instruction Program. You were selected as a possible participant in this study because of your enrollment in English Composition 2 and your participation in Library Instruction.

The study will consist of an open-ended questionnaire at the end of each instruction session. If you choose to participate, you will be given 5 min to complete the exercise. If you choose not to participate you will not be penalized. Any information that can be identified with you that is obtained during this study will remain confidential. You are free to withdraw your consent and discontinue participation at any time without penalty.

If you have any questions about this study, or would like information regarding the results, please feel free to contact the [SWOSU Libraries]. If you have questions regarding your rights as a research subject, contact the [Chair of the Protection of Human Subjects Committee].

Your signature indicates that you:

1. Have read and understood the information provided above.

2. You willingly agree to participate.

3. You may withdraw your consent at any time and discontinue participation without penalty.

4. You will receive a copy of this form.

5. You are 18 years of age or older.

I agree to allow researchers to use my student ID number and to contact me in order to participate in possible follow-up focus groups at a later date.

Signature

Date

Table 2-Demographics Questionnaire

Student ID \#:

Please check or write in your responses below:

Age

Year in school

Freshman

Sophomore

Junior

Senior

Current or estimated GPA
$3.5-4.0$
$3.0-3.4$
$2.5-2.9$
$2.0-2.4$
1.5 or below -1.9

Sex

$\mathrm{M}$

Have you participated in a Library Instruction session at the SWOSU

Libraries during a previous semester?

Yes

No

Are you a transfer student from a college or university other than SWOSU?

Yes No 
Table 3-Critical Incident Questionnaire

Student ID \#:

\title{
In one or two sentences, please respond to each of the questions below about your experiences in today's Library Instruction class:
}

\author{
1. At what moment in the class today did you feel like you most understood \\ the instructional content?
}

2. At what moment in the class today did you feel most confused about the instructional content?

3. What was your most rewarding experience in today's class?

4. What was your most surprising experience in today's class?

5. Was there information presented in today's class that is still unclear to you? If so, please describe.

Table 4-Framework for Reflective Thinking Scale

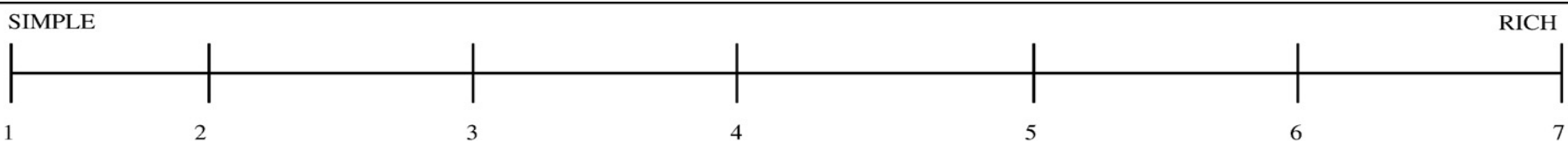

Level 1

"No descriptive language." Responses contain: no information or a lack of substantive information to identify a theme or critical incident.

Level 2

"Simple, layperson description" Responses contain: a generic description, regardless of how the response is and tend to be scored lower unless that statement holds a unique significance.

Level 3

"Events labeled with appropriate terms." Responses contain: a simplistic description that identifies specific terminology, concepts, lecture material, and/or proper names of research sources. For example, the term "worksheet" versus the generic term "assignment" or the term "database" versus the generic term "Internet."

Level 4

"Explanation with tradition or personal preference given as the rational." Responses contain: descriptions that include personal opinion or preference in the use of their new knowledge; statements of how s/he prefers to learn and/or work with new knowledge; or acknowledging previous instruction by drawing a comparison with their current experience and a previous experience(s).

Level 5

"Explanation with principle or theory given as the rationale." Responses contain: descriptions that reflect any type of methodology or concept taught during library instruction regardless of the positive or negative value assigned to it by the student and its application in the learning process.

Level 6

"Explanation with principle/theory and consideration of context factors." Responses contain: descriptions that consider the context of new knowledge by identifying the importance and benefits it holds for future assignments and research or the acknowledgment of impact of learning such as a better, more effective, and/or more efficient method or process.

Level 7

"Explanation with consideration of ethical, moral, political issues." Responses contain: descriptions that consider the ethical, moral and political implications of knowledge and/or learning, assigning personal judgments, positive or negative, to their experience, and that validate how this new knowledge influences their view of the outside world. 
Figure 1- Descriptive Statistics by Variable Groupings $(x=3.44)$

\begin{tabular}{|c|c|c|c|c|c|}
\hline & & $\mathbf{n}$ & $\begin{array}{r}\text { Reflective } \\
\text { Thinking }\end{array}$ & $\begin{array}{c}\text { Std. } \\
\text { Deviation }\end{array}$ & $\begin{array}{l}\text { Std. Error } \\
\text { Mean }\end{array}$ \\
\hline \multirow{4}{*}{$\begin{array}{l}\text { Academic } \\
\text { Achievement }\end{array}$} & $<=1.9$ & 15 & 3.100 & 1.1680 & 0.3016 \\
\hline & $2.0-2.4$ & 32 & 3.016 & 1.0198 & 0.1803 \\
\hline & $2.5-2.9$ & 88 & 3.307 & 1.2304 & 0.1312 \\
\hline & $3.0-3.4$ & 105 & 3.557 & 1.1400 & 0.1113 \\
\hline \multirow[t]{2}{*}{ Gender } & Male & 145 & 3.083 & 1.1903 & 0.0988 \\
\hline & Female & 195 & 3.721 & 1.1710 & 0.0839 \\
\hline \multirow[t]{2}{*}{ Semester } & Fall & 104 & 3.909 & 1.3416 & 0.1316 \\
\hline & Spring & 245 & 3.245 & 1.1094 & 0.0709 \\
\hline \multirow[t]{4}{*}{ Age Category } & 18 & 82 & 3.512 & 1.2272 & 0.1355 \\
\hline & 19 & 125 & 3.468 & 1.1390 & 0.1019 \\
\hline & $20-29$ & 87 & 3.443 & 1.3150 & 0.1410 \\
\hline & $>=30$ & 45 & 3.300 & 1.2676 & 0.1890 \\
\hline \multirow[t]{4}{*}{ Year in School } & Fresh & 212 & 3.408 & 1.1436 & 0.0785 \\
\hline & Soph & 96 & 3.589 & 1.3514 & 0.1379 \\
\hline & \begin{tabular}{|l} 
Jun \\
\end{tabular} & 21 & 3.214 & 1.4015 & 0.3058 \\
\hline & Sen & 10 & 3.350 & 1.0814 & 0.3420 \\
\hline \multirow{2}{*}{$\begin{array}{l}\text { Previous Library } \\
\text { Instruction }\end{array}$} & No & 213 & 3.505 & 1.2160 & 0.0833 \\
\hline & Yes & 127 & 3.354 & 1.2233 & 0.1086 \\
\hline \multirow[t]{2}{*}{ Transfer Student } & No & 306 & 3.412 & 1.2013 & 0.0687 \\
\hline & Yes & 33 & 3.727 & 1.3293 & 0.2314 \\
\hline \multirow[t]{4}{*}{ Librarian Code } & Lib1 & 21 & 2.762 & 1.0077 & 0.2199 \\
\hline & \begin{tabular}{|l} 
Lib2 \\
\end{tabular} & 181 & 3.616 & 1.2922 & 0.0960 \\
\hline & Lib3 & 140 & 3.382 & 1.0722 & 0.0906 \\
\hline & Lib4 & 7 & 2.214 & 1.3496 & 0.5101 \\
\hline \multirow[t]{2}{*}{ Day of Week } & MWF & 147 & 3.483 & 1.2787 & 0.1055 \\
\hline & TR & 202 & 3.413 & 1.1776 & 0.0829 \\
\hline \multirow[t]{2}{*}{ Time of Day } & AM & 278 & 3.514 & 1.2247 & 0.0735 \\
\hline & PM & 71 & 3.162 & 1.1673 & 0.1385 \\
\hline
\end{tabular}

Figure 2-ANOVA Test of Regression Model Strength

ANOVA Strength of Intraclass Correlation

\begin{tabular}{|ll|r|r|r|r|r|}
\hline & & \multicolumn{1}{c|}{ Sum of } & df & Mean Square & F & Sig \\
\hline Between People & & 1035.315 & 347 & 2.984 & & \\
Within People & Between Items & 5.703 & 1 & 5.703 & 9.127 & .003 \\
& Residual & 216.797 & 347 & .625 & & \\
& Total & 222.500 & 348 & .639 & & \\
Total & & 1257.815 & 695 & 1.810 & & \\
\hline
\end{tabular}

Figure 3-Regression Analysis Model Summary

Model Summary

\begin{tabular}{|c|c|c|c|c|c|c|c|c|c|}
\hline \multirow[b]{2}{*}{ Model } & \multirow[b]{2}{*}{$\mathrm{R}$} & \multirow[b]{2}{*}{$\begin{array}{c}\text { R } \\
\text { Square }\end{array}$} & \multirow[b]{2}{*}{$\begin{array}{c}\text { Adjusted R } \\
\text { Square }\end{array}$} & \multirow[b]{2}{*}{$\begin{array}{l}\text { Std. Error of } \\
\text { the Estimate }\end{array}$} & \multicolumn{5}{|c|}{ Change Statistics } \\
\hline & & & & & $\begin{array}{l}\text { R Square } \\
\text { Change }\end{array}$ & F Change & $d f 1$ & df2 & $\begin{array}{l}\text { Sig. F } \\
\text { Change }\end{array}$ \\
\hline 1 & 0.449 & 0.202 & 0.177 & 1.1039 & 0.202 & 8.104 & 10 & 321 & 0.000 \\
\hline
\end{tabular}


Figure 4-Histogram of Standardized Residuals

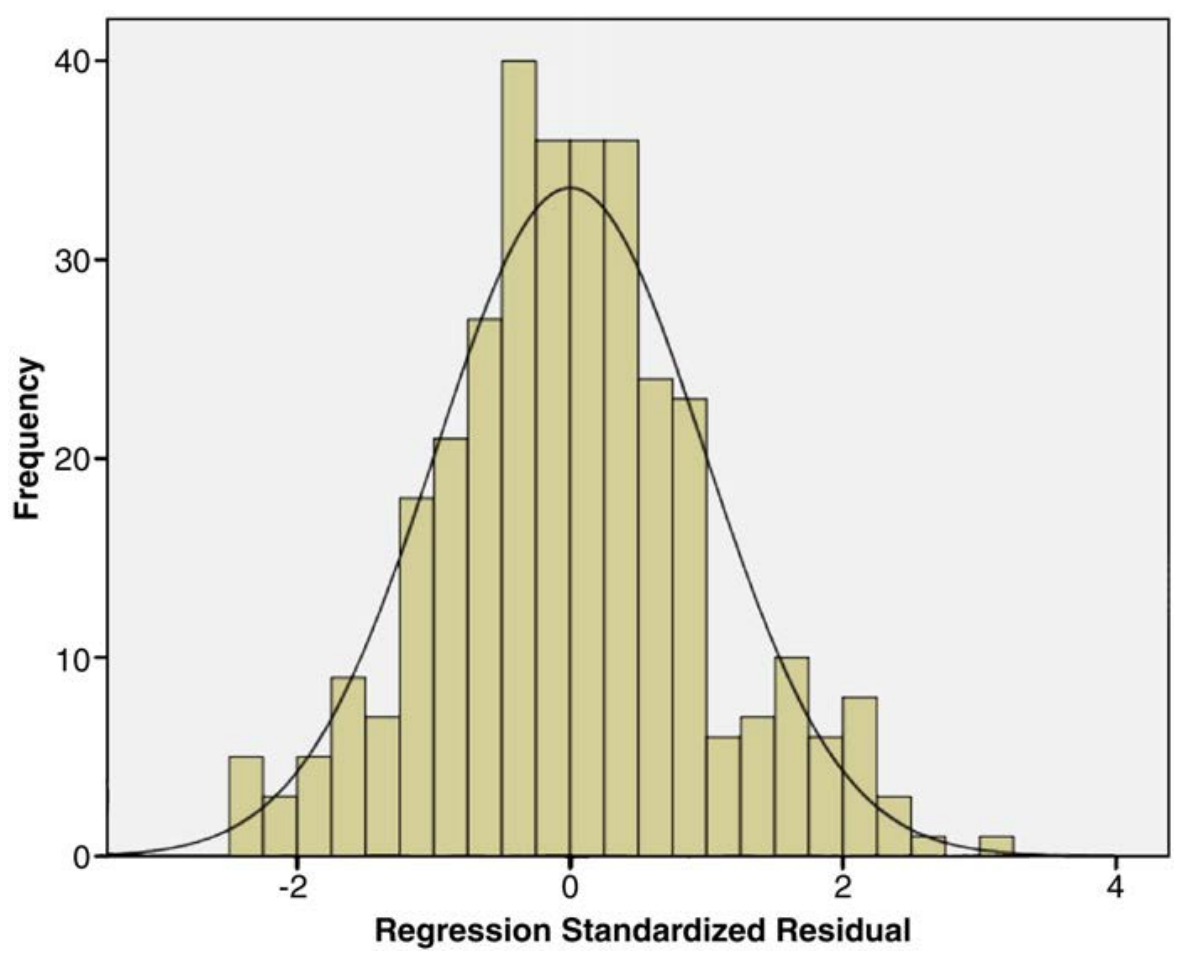

Figure 5-Normal P-P Plot of Observed and Predicted Standardized Residuals along Regression Line

Figure 6-Scatterplot of Observed and Predicted Residuals

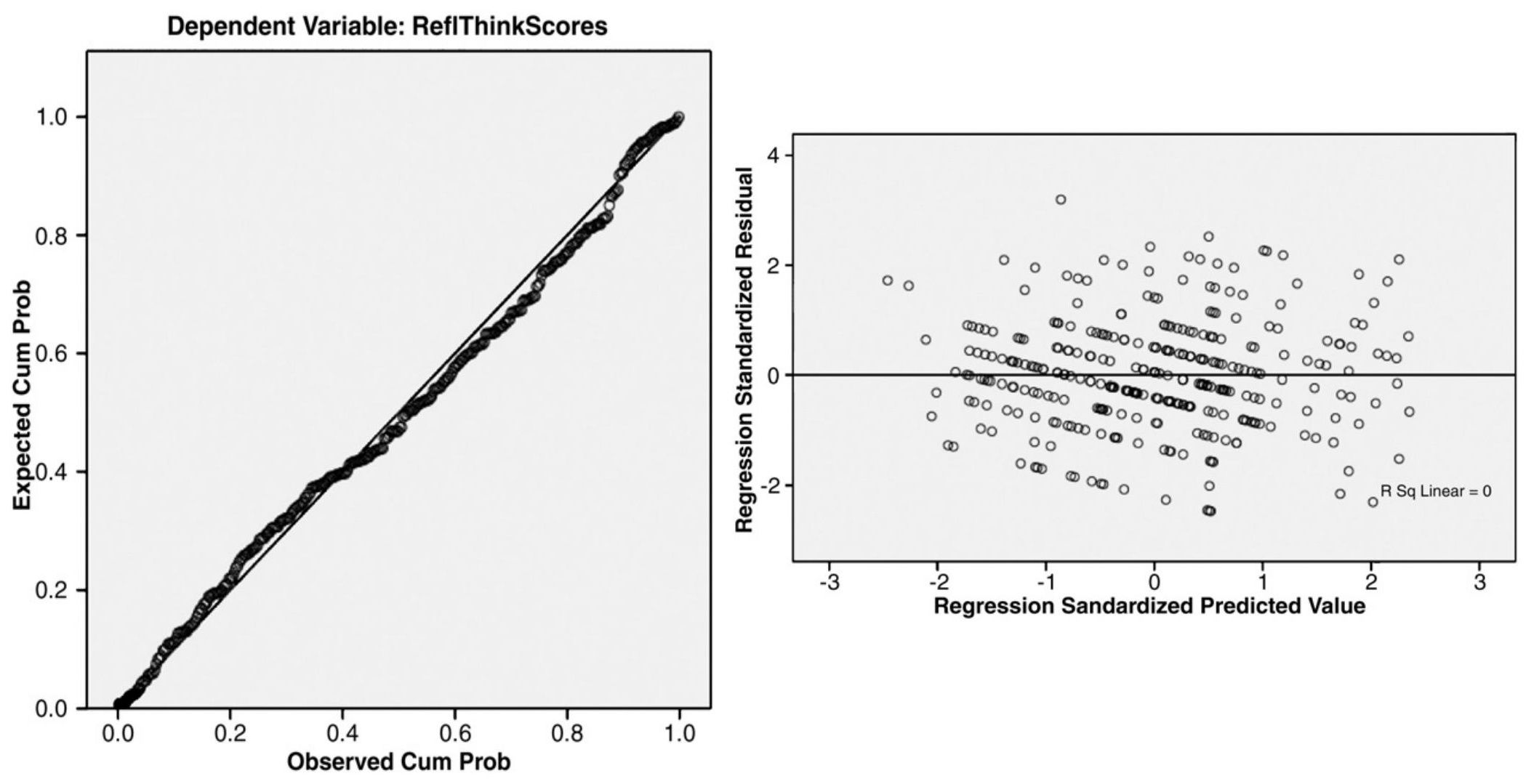


Figure 7-Multiple Regression Analysis

\begin{tabular}{|c|c|c|c|c|c|c|c|c|c|c|c|c|c|}
\hline \multirow[b]{2}{*}{ Mod } & & \multicolumn{2}{|c|}{$\begin{array}{c}\text { Unstandardized } \\
\text { Coefficients }\end{array}$} & \multirow{2}{*}{\begin{tabular}{|c|}
$\begin{array}{c}\text { Standardized } \\
\text { Coefficients }\end{array}$ \\
Beta \\
\end{tabular}} & \multirow[b]{2}{*}{$t$} & \multirow[b]{2}{*}{ Sig. } & \multicolumn{2}{|c|}{$\begin{array}{l}95 \% \text { Confidence } \\
\text { Interval for B }\end{array}$} & \multicolumn{3}{|c|}{ Correlations } & \multicolumn{2}{|c|}{$\begin{array}{l}\text { Collinearity } \\
\text { Statistics }\end{array}$} \\
\hline & & B & Std. Error & & & & $\begin{array}{l}\text { Lower } \\
\text { Bound }\end{array}$ & $\begin{array}{l}\text { Upper } \\
\text { Bound }\end{array}$ & $\begin{array}{l}\text { Zero- } \\
\text { order }\end{array}$ & Partial & Part & Tolerance & VIF \\
\hline \multirow[t]{11}{*}{1} & (Constant) & 4.672 & 0.447 & & 10.453 & 0.000 & 3.793 & 5.551 & & & & & \\
\hline & AcadAchieve & 0.165 & 0.056 & 0.152 & 2.951 & 0.003 & 0.055 & 0.275 & 0.173 & 0.163 & 0.147 & 0.938 & 1.066 \\
\hline & Gender & -0.670 & 0.126 & -0.273 & -5.332 & 0.000 & -0.917 & -0.423 & -0.270 & -0.285 & -0.266 & 0.951 & 1.052 \\
\hline & Semester & -0.820 & 0.158 & -0.304 & -5.181 & 0.000 & -1.131 & -0.509 & -0.266 & -0.278 & -0.258 & 0.722 & 1.385 \\
\hline & AgeCatEffectCoded & -0.052 & 0.079 & -0.033 & -0.648 & 0.517 & -0.208 & 0.105 & 0.015 & -0.036 & -0.032 & 0.971 & 1.030 \\
\hline & YearSchool & -0.235 & 0.098 & -0.144 & -2.399 & 0.017 & -0.427 & -0.042 & -0.004 & -0.133 & -0.120 & 0.695 & 1.439 \\
\hline & PrevLI & -0.071 & 0.129 & -0.028 & -0.549 & 0.584 & -0.325 & 0.183 & -0.050 & -0.031 & -0.027 & 0.938 & 1.066 \\
\hline & Transfer & 0.409 & 0.228 & 0.096 & 1.792 & 0.074 & -0.040 & 0.857 & 0.071 & 0.100 & 0.089 & 0.859 & 1.164 \\
\hline & LibCodeEffectCoded & -0.052 & 0.068 & -0.041 & -0.769 & 0.443 & -0.187 & 0.082 & -0.097 & -0.043 & -0.038 & 0.877 & 1.140 \\
\hline & Day & -0.013 & 0.130 & -0.005 & -0.100 & 0.921 & -0.268 & 0.242 & 0.038 & -0.006 & -0.005 & 0.893 & 1.120 \\
\hline & TimeDay & 0.232 & 0.163 & 0.076 & 1.429 & 0.154 & -0.087 & 0.552 & 0.113 & 0.080 & 0.071 & 0.872 & 1.146 \\
\hline
\end{tabular}

Figure 8-Collinearity Diagnostics of Multiple Regression Dimensions

Collinearity Diagnostics

\begin{tabular}{|c|c|c|c|c|c|c|c|c|c|c|c|c|c|c|}
\hline \multirow[b]{2}{*}{ Mode } & \multirow[b]{2}{*}{ Dimension } & \multirow[b]{2}{*}{ Eigenvalue } & \multirow[b]{2}{*}{$\begin{array}{c}\text { Condition } \\
\text { Index }\end{array}$} & \multicolumn{11}{|c|}{ Variance Proportions } \\
\hline & & & & (Constant) & $\begin{array}{c}\text { Acad } \\
\text { Achieve }\end{array}$ & Gender & Semester & $\begin{array}{c}\text { AgeCat } \\
\text { Effect } \\
\text { Coded }\end{array}$ & $\begin{array}{l}\text { Year in } \\
\text { School }\end{array}$ & $\begin{array}{c}\text { Prev } \\
\text { LI }\end{array}$ & Transfer & $\begin{array}{c}\text { LibCode } \\
\text { Effect } \\
\text { Coded }\end{array}$ & Day & TimeDay \\
\hline 1 & 1 & 6.074 & 1.000 & 0.00 & 0.00 & 0.01 & 0.00 & 0.00 & 0.00 & 0.01 & 0.00 & 0.00 & 0.01 & 0.00 \\
\hline & 2 & 1.028 & 2.431 & 0.00 & 0.00 & 0.01 & 0.00 & 0.01 & 0.00 & 0.00 & 0.06 & 0.68 & 0.03 & 0.00 \\
\hline & 3 & 0.989 & 2.479 & 0.00 & 0.00 & 0.01 & 0.00 & 0.90 & 0.00 & 0.01 & 0.00 & 0.01 & 0.00 & 0.00 \\
\hline & 4 & 0.932 & 2.552 & 0.00 & 0.00 & 0.01 & 0.00 & 0.00 & 0.00 & 0.05 & 0.67 & 0.07 & 0.00 & 0.00 \\
\hline & 5 & 0.620 & 3.131 & 0.00 & 0.00 & 0.00 & 0.00 & 0.01 & 0.00 & 0.53 & 0.05 & 0.08 & 0.24 & 0.01 \\
\hline & 6 & 0.538 & 3.359 & 0.00 & 0.00 & 0.65 & 0.00 & 0.06 & 0.00 & 0.08 & 0.04 & 0.02 & 0.19 & 0.00 \\
\hline & 7 & 0.422 & 3.794 & 0.00 & 0.01 & 0.29 & 0.01 & 0.01 & 0.01 & 0.25 & 0.00 & 0.01 & 0.41 & 0.01 \\
\hline & 8 & 0.173 & 5.923 & 0.00 & 0.00 & 0.01 & 0.06 & 0.00 & 0.58 & 0.03 & 0.13 & 0.01 & 0.00 & 0.00 \\
\hline & 9 & 0.143 & 6.513 & 0.00 & 0.04 & 0.01 & 0.02 & 0.00 & 0.02 & 0.03 & 0.00 & 0.09 & 0.09 & 0.94 \\
\hline & 10 & 0.068 & 9.458 & 0.01 & 0.74 & 0.02 & 0.19 & 0.01 & 0.09 & 0.01 & 0.03 & 0.03 & 0.00 & 0.00 \\
\hline & 11 & 0.013 & 21.223 & 0.99 & 0.20 & 0.00 & 0.72 & 0.01 & 0.29 & 0.00 & 0.01 & 0.01 & 0.02 & 0.03 \\
\hline
\end{tabular}

Figure 9-Multiple Regression Coefficients Compared to Ridge Regression Coefficients

\begin{tabular}{|c|c|c|c|c|c|c|c|}
\hline \multirow[b]{2}{*}{ Mod } & & \multicolumn{2}{|c|}{$\begin{array}{l}\text { Multiple Regression } \\
\text { Unstandardized } \\
\text { Coefficients }\end{array}$} & \multirow{2}{*}{$\begin{array}{c}\text { Multiple } \\
\begin{array}{c}\text { Regression } \\
\text { Standardized } \\
\text { Coefficients }\end{array} \\
\text { Beta }\end{array}$} & \multicolumn{2}{|c|}{$\begin{array}{l}\text { Ridge Regression } \\
\text { Unstandardized } \\
\text { Coefficients }\end{array}$} & \multirow{2}{*}{$\begin{array}{c}\text { Ridge } \\
\text { Regression } \\
\begin{array}{c}\text { Standardized } \\
\text { Coefficients }\end{array} \\
\text { Beta }\end{array}$} \\
\hline & & $\mathrm{B}$ & $\begin{array}{l}\text { Std. } \\
\text { Error }\end{array}$ & & $\mathrm{B}$ & Std. Error & \\
\hline \multirow[t]{11}{*}{1} & (Constant) & 4.672 & 0.447 & & 3.946 & 0.572 & \\
\hline & AcadAchieve & 0.165 & 0.056 & 0.152 & 0.156 & 0.057 & 0.144 \\
\hline & Gender & -0.670 & 0.126 & -0.273 & 0.645 & 0.124 & -0.263 \\
\hline & Semester & -0.820 & 0.158 & -0.304 & -0.861 & 0.156 & -0.320 \\
\hline & AgeCat & -0.052 & 0.079 & -0.033 & -0.055 & 0.076 & -0.044 \\
\hline & YearSchool & -0.235 & 0.098 & -0.144 & -0.207 & 0.108 & -0.127 \\
\hline & PrevLI & -0.071 & 0.129 & -0.028 & -0.060 & 0.129 & -0.024 \\
\hline & Transfer & 0.409 & 0.228 & 0.096 & 0.417 & 0.228 & 0.098 \\
\hline & LibrCode & -0.052 & 0.068 & -0.041 & 0.037 & 0.102 & 0.019 \\
\hline & Day & -0.013 & 0.130 & -0.005 & 0.026 & 0.127 & 0.011 \\
\hline & TimeDay & 0.232 & 0.163 & 0.076 & -0.274 & 0.166 & -0.090 \\
\hline
\end{tabular}


Figure 10-Variance Explained

\begin{tabular}{|c|c|c|c|c|c|}
\hline \multirow{2}{*}{\multicolumn{2}{|c|}{ Model }} & \multirow[b]{2}{*}{ Zero-order } & $\begin{array}{l}\text { Explained Variance in Critical } \\
\text { Reflection Scores for Each } \\
\text { Variable without Holding Other } \\
\text { Variables Constant }\end{array}$ & & \multirow[t]{2}{*}{$\begin{array}{l}\text { Explained Variance in Critical } \\
\text { Reflection Scores for Each } \\
\text { Variable while Holding Other } \\
\text { Variables Constant } \\
\end{array}$} \\
\hline & & & & Part & \\
\hline 1 & (Constant) & & & & \\
\hline & AcadAchieve & 0.173 & $2.99 \%$ & 0.147 & $2.16 \%$ \\
\hline & Gender & -0.270 & $7.29 \%$ & -0.266 & $7.08 \%$ \\
\hline & Semester & -0.266 & $7.08 \%$ & -0.258 & $6.66 \%$ \\
\hline & AgeCat & 0.015 & & -0.032 & \\
\hline & YearSchool & -0.004 & $0.00 \%$ & -0.120 & $1.44 \%$ \\
\hline & PrevLI & -0.050 & & -0.027 & \\
\hline & Transfer & 0.071 & & 0.089 & \\
\hline & LibrCode & -0.097 & & -0.038 & \\
\hline & Day & 0.038 & & -0.005 & \\
\hline & TimeDay & 0.113 & & 0.071 & \\
\hline
\end{tabular}




\section{Notes and References}

${ }^{1}$ Carter Victor Good, ed., Dictionary of Education, 2nd ed. (New York: McGraw-Hill, 1959): 571.

${ }^{2}$ Peter Jarvis and A. L. Wilson, "Critical thinking," International Dictionary of Adult and Continuing Education, 2nd ed., ed. Peter Jarvis (London: Routledge, 1999): 41.

${ }^{3}$ Peter Jarvis and Colin Griffin (eds.), Adult and Continuing Education: Major Themes in Education, Volume IV, (London: Routledge, 2003): 207.

${ }^{4}$ Ethelene Whitmire, "Development of Critical Thinking Skills: An analysis of academic library experiences and other measures," College \& Research Libraries 59, no. 3 (1998): 266-73.

${ }^{5}$ Nahyun Kwon, "A Mixed-methods Investigation of the Relationship between Critical Thinking and Library Anxiety among Undergraduate Students in Their Information Search Process," College \& Research Libraries 69, no. 2 (2008): 117-131.

6 "Information Literacy Competency Standards for Higher Education: Standards, Outcomes, and Performance Indicators," Association of College \& Research Libraries (January 2000), http://www.ala.org/ala/acrl/acrlstandards/informationliteracycompetency.htm

${ }^{7}$ Donald L. Gilstrap and Jason Dupree, "Assessing Learning, Critical Reflection, and Quality Educational Outcomes: The Critical Incident Questionnaire," College \& Research Libraries, 69, no. 5 (2008): 407-426.

${ }^{8}$ Stephen D. Brookfield, Becoming a Critically Reflective Teacher, (San Francisco: Jossey-Bass, 1995).

${ }^{9}$ Georgea M. Sparks-Langer, Joanne M. Simmons, Marvin Pasch, Amy Colton, and Alane Starko, "Reflective Pedagogical Thinking: How Can We Promote It and Measure It?," Journal of Teacher Education 41, no. 4 (1990): 23-32.

${ }^{10}$ Stephen D. Brookfield, Becoming a Critically Reflective Teacher, 1995.

${ }^{11}$ Stephen D. Brookfield, The Skillful Teacher: On Technique, Trust, and Responsiveness in the Classroom, (San Francisco: Jossey-Bass, 1990); Brookfield, Becoming a Critically Reflective Teacher, 1995; Stephen D. Brookfield, "Experiential Pedagogy: Grounding Teaching in Students' Learning," The Journal of Experiential Education 19, no. 2 (1996): 62-68; Stephen D. Brookfield, The Power of Critical Theory: Liberating Adult Learning and Teaching, (San Francisco: Jossey-Bass, 2005).

${ }^{12}$ David Tripp, Critical Incidents in Teaching: Developing Professional Judgment, (London: Routledge, 1993).

${ }^{13}$ Peter Woods, Critical Events in Teaching and Learning, (Washington, D.C.: Falmer Press, 1993).

${ }^{14}$ Ibid.

${ }^{15}$ Ibid., p. 142

${ }^{16}$ Tripp, Critical Incidents in Teaching, 1993.

${ }^{17}$ Vivien Burr, Gender and Social Psychology, (London: Routledge, 1998); Sandra Lipsitz Bem, The Lenses of Gender: Transforming the Debate on Sexual Inequality, (New Haven, CT: Yale University Press, 1993); Carol Gilligan, In a Different Voice: Psychological Theory and Women's Development, (Cambridge, MA: Harvard University Press, 1993).

${ }^{18}$ Tripp, Critical Incidents in Teaching and Learning, 1993.

${ }^{19}$ Brookfield, The Skillful Teacher, 1990; Brookfield, Becoming a Critically Reflective Teacher, 1995; Brookfield, "Experiential Pedagogy," 1996; Brookfield, The Power of Critical Theory, 2005.

${ }^{20}$ Whitmire, "Development of Critical Thinking Skills," 1998.

${ }^{21}$ Ibid.

${ }^{22}$ Kwon, "A Mixed-methods Investigation," 2008.

${ }^{23}$ Shinichi Monoi, Nancy O'Hanlon, and Karen R. Diaz, “Online Searching Skills: Development of an Inventory to Assess Self-Efficacy," Journal of Academic Librarianship 31, no. 2 (2005): 98-105; Lisa Tsui, "Effects of Campus Culture on Students' Critical Thinking," Review of Higher Education 23, no. 4 (2000): 421-441; Donna H. Redmann, Judith J. Lambrecht, and Wanda L. Stitt-Gohdes, "The Critical Incident Technique: A Tool for Qualitative Research," Delta Pi Epsilon Journal 42, no. 3 (2000): 132-53; Xi Shi, Patricia J. Holahan, and M. Peter Jurkat, "Satisfaction Formation Processes in Library User Understanding Multisource Effects." Journal of Academic Librarianship 30, no. 2 (2004): 122-31; Graham Walton and Sarah Nettleton, "Reflective and Critical Thinking in User Education Progammes," British Journal of Academic Librarianship 7, no. 1 (1992): 31-43; Whitmire, "Development of Critical Thinking Skills," 1998; Ethelene Whitmire, "The Relationship between Undergraduates' Background Characteristics and College Experiences and Their Academic Library Use," College \& Research Libraries 62, no. 6 (2001): 528-40; Jacqueline Kracker, "Research Anxiety and Students' Perceptions of Research: Experiment. Part II. Content Analysis of Their Writings on Two Experiences," Journal of the 
American Society for Information Science and Technology 53, no. 4 (2002): 295-307; Kathleen Dunn, "Assessing Information Literacy Skills in the California State University: A Progress Report," The Journal of Academic Librarianship 28, no. 3 (2002): 26-35; Patricia Davitt Maughan, “Assessing Information Literacy among Undergraduates: A Discussion of the Literature and the University of California-Berkeley Assessment Experience," College \& Research Libraries 26, no. 1 (2001): 71-85.

${ }^{24}$ Georgea M. Sparks-Langer, Joanne M. Simmons, Marvin Pasch, Amy Colton, and Alane Starko, "Reflective Pedagogical Thinking How Can We Promote It and Measure It?," Journal of Teacher Education 41, no. 4 (1990): $23-32$.

${ }^{25}$ Robert Mills Gagné, “Learning Hierarchies,” In Instructional design: Readings, ed. M. D. Merrill (Englewood Cliffs, NJ: Prentice-Hall, 1968): 118-131.

${ }^{26}$ Max Van Manen, "Linking Ways of Knowing with Ways of Being Practical," Curriculum Inquiry 6 (1977): 205 228.

${ }^{27}$ David A. Kolb, Experiential Learning: Experience as the Source of Learning and Development, (Englewood Cliffs, NJ: Prentice-Hall, 1984).

${ }^{28}$ Donald A. Schön, The Reflective Practitioner: How Professionals Think in Action, (Averbury, U.K.: Ashgate Publishing Limited, 1991).

${ }^{29}$ Paula M. Short and James S. Rinehart, "Reflection as a Means of Developing Expertise," Educational Administration Quarterly 29, no. 4 (November 1993): 501-521.

${ }^{30}$ Georgea M. Sparks-Langer, Alane J. Starko, Marvin Pasch, Wendy Burke, Christella D. Moody, and Trevor G. Garner, Teaching as Decision Making: Successful Practices for the Secondary Teacher, 2nd ed. (Upper Saddle River, NJ: Prentice Hall, 2003).

${ }^{31}$ Gilstrap and Dupree, "Assessing Learning, Critical Reflection, and Quality Educational Outcomes,” 2008.

32 "2005 Fact Book," Office of Institutional Research, Southwestern Oklahoma State University, http://www.swosu.edu/administration/research/2005/factbook.asp

33 Jacob Cohen and Patricia Cohen, Applied Multiple Regression/ Correlation Analysis for the Behavioral Sciences 2nd ed. (London:Lawrence Erlbaum Associates, 1983).

${ }^{34}$ Sparks-Langer et al., "Reflective Pedagogical Thinking," 1990.

${ }^{35}$ Patrick E. Shrout and Joseph L. Fleiss, "Intraclass Correlations: Uses in Assessing Rater Reliability," Psychological Bulletin 86, no. 2 (1979): 420-428; G. David Garson, "Reliability Analysis," College of Humanities and Social Sciences, North Carolina State University http://www2.chass.ncsu.edu/garson/pa765/reliab.htm

${ }^{36}$ Tripp, Critical Incidents in Teaching, 1993;Woods, Critical Events in Teaching and Learning, 1993; Brookfield, Becoming a Critically Reflective Teacher, 1995; Brookfield, The Power of Critical Theory, 2005.

${ }^{37}$ Mark H. Licht, "Multiple Regression and Correlation," Reading and Understanding Multivariate Statistics, eds. Laurence G. Grimm and Paul R. Yarnold, (Washington, D.C.: American Psychological Association, 1998): 19-64; William H. Crown, Statistical Models for the Social and Behavioral Sciences: Multiple Regression and LimitedDependent Variable Models, (London: Praeger, 1998); Cohen and Cohen, Applied Multiple Regression, 1983.

${ }^{38}$ John Fox, Regression Diagnostics, Quantitative Applications in the Social Sciences, ed. Michael S. Lewis-Beck, Series Number 07-079, (London: Sage Publications, 1991); Fred N. Kerlinger and Elazar J. Pedhazer, Multiple Regression in Behavioral Research, (New York: Holt, Rinehart and Winston, Inc., 1973); Crown, Statistical Models, 1998; Cohen and Cohen, Applied Multiple Regression, 1983; Licht, "Multiple Regression,” 1998.

${ }^{39}$ Cohen and Cohen, Applied Multiple Regression, 1983.

${ }^{40}$ Sam Kash Kachigan, Multivariate Statistical Analysis, 2nd ed. (New York: Radius Press, 1991); Jacob Cohen, Statistical Power Analysis for the Social Sciences, 2nd ed. (New York: Lawrence Erlbaum, 1988).

${ }^{41}$ Cohen and Cohen, Applied Multiple Regression, 1983; Kerlinger and Pedhazer, Multiple Regression, 1973; Licht, "Multiple Regression," 1998; Kachigan, Multivariate Statistical Analysis, 1991; Fox, Regression Diagnostics, 1991.

42 Tripp, Critical Incidents in Teaching, 1993;Woods, Critical Events in Teaching and Learning, 1993; Brookfield, Becoming a Critically Reflective Teacher, 1995; Brookfield, The Power of Critical Theory, 2005.

${ }^{43}$ James Jaccard and Robert Turrisi, Interaction Effects in Multiple Regression, Quantitative Applications in the Social Sciences, ed. Micheal S. Lewis-Beck, Series Number 07-72, (London: Sage Publications, 2003); Kerlinger and Pedhazur, Multiple Regression, 1973; Cohen and Cohen, Applied Multiple Regression, 1983.

${ }^{44}$ Crown, Statistical Models, 1998.

${ }^{45}$ Fox, Regression Diagnostics, 1991; Jaccard and Turrisi, Interaction Effects, 2003; Crown, Statistical Models, 1998. 
${ }^{46}$ Fox, Regression Diagnostics,1991; Cohen and Cohen, Applied Multiple Regression, 1983; Jaccard and Turrisi, Interaction Effects, 2003; Licht, "Multiple Regression,” 1998.

${ }^{47}$ Licht, "Multiple Regression," 1998.

${ }^{48}$ Jaccard and Turrisi, Interaction Effects, 2003.

${ }^{49}$ A. Hoerl and R. Kennard, "Ridge regression: Biased estimation for nonorthogonal problems," Technometrics 12 (1970): 69-82; Cohen and Cohen, Applied Multiple Regression, 1983.

${ }^{50} \mathrm{Ibid}$.

${ }^{51}$ Fox, Regression Diagnostics, 2000; Cohen and Cohen, AppliedMultiple Regression, 1983; Kerlinger and Pedhazer, Multiple Regression, 1973.

${ }^{52}$ Ibid.

${ }^{53}$ Crown, Statistical Models, 1998.

${ }^{54}$ John Fox, Multiple and Generalized Nonparametric Regression, Quantitative Applications in the Social Sciences, ed. Michael S. Lewis-Beck, (Thousand Oaks, CA: Sage, 2000).

${ }_{55}^{55}$ Brookfield, Becoming a Critically Reflective Teacher, 1995.

${ }^{56}$ Tripp, Critical Incidents in Teaching, 1993;Woods, Critical Events in Teaching and Learning, 1993.

${ }^{57}$ Whitmire, "Development of Critical Thinking Skills," 1998.

${ }^{58}$ Jarvis and Griffin (eds.), Adult and Continuing Education, 2003, p. 207.

${ }^{59}$ David N. Perkins and Graviel Salomon, "Transfer of Learning," International Encyclopedia of Education, 2nd ed., ed. Torsten Husén, (Oxford, England: Pergamon Press, 1992).

${ }^{60}$ ACRL, 2000. 